\title{
Correction to: Living with pathological narcissism: a qualitative study
}

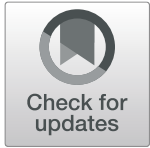

Nicholas J. S. Day, Michelle L. Townsend and Brin F. S. Grenyer

Correction to: Borderline Personal Disord Emot Dysregul 7, 19 (2020).

$$
\text { https://doi.org/10.1186/s40479-020-00132-8 }
$$

Following publication of this article [1], it is reported that the reference 35 contained an error.

The correct reference 35 should be:

35. Green A, Charles K. Voicing the Victims of Narcissistic Partners: A Qualitative Analysis of Responses to Narcissistic Injury and Self-Esteem Regulation. SAGE Open. 2019;9(2). https://doi.org/10.1177/2158244019846693.

The original article has been updated.

Published online: 22 January 2022

\section{Reference}

1. Day NJS, Townsend ML, Grenyer BFS. Living with pathological narcissism: a qualitative study. Borderline Personal Disord Emot Dysregul. 2020;7:19.

https://doi.org/10.1186/s40479-020-00132-8.

The original article can be found online at https://doi.org/10.1186/s40479020-00132-8.

* Correspondence: grenyer@uow.edu.au

Illawarra Health and Medical Research Institute and School of Psychology,

University of Wollongong Australia, Wollongong, NSW, Australia

(c) The Author(s). 2022 Open Access This article is licensed under a Creative Commons Attribution 4.0 International License, which permits use, sharing, adaptation, distribution and reproduction in any medium or format, as long as you give appropriate credit to the original author(s) and the source, provide a link to the Creative Commons licence, and indicate if changes were made. The images or other third party material in this article are included in the article's Creative Commons licence, unless indicated otherwise in a credit line to the material. If material is not included in the article's Creative Commons licence and your intended use is not permitted by statutory regulation or exceeds the permitted use, you will need to obtain permission directly from the copyright holder. To view a copy of this licence, visit http://creativecommons.org/licenses/by/4.0/ The Creative Commons Public Domain Dedication waiver (http://creativecommons.org/publicdomain/zero/1.0/) applies to the data made available in this article, unless otherwise stated in a credit line to the data. 